\title{
Reserrch Article: Impact of front line demonstration on production and productivity of summer moong
}

\author{
ם. S. BHARGAV, NISHITH GUPTA, ANKITA PANDEY, NEERJA PATEL \\ AND A. K. DIXIT
}

Article Chronicle :

SUMMARY : Cluster Frontline Demonstrationson summer moong were conducted by Krishi Vigyan Received :

17.07.2017;

Accepted :

01.08 .2017

KeY Words :

Front line

demonstration,

Production,

Productivity,

Moong

Author for correspondence :

\section{K. S. BHARGAV}

Krishi Vigyan Kendra, (R.V.S.K.V.V.), DEWAS

(M.P.) INDIA

Email: ksbhargav@

rediffmail.com
Kendra, RVSKVV, Dewas in the different village of district with main objective to boost the production and productivity of moong with latest and specific technologies.Moong variety of medium duration HUM-12 was used for demonstrations. The farmers followed the full package of practices like proper seed rate, seed treatment with biofertilizer, Trichoderma viride, fertilizer application on soil test value, weed and water management, IPM practices etc.Result of front line demonstrations indicated thaton an average of $24 \%$ more yield of moong was found as compared to farmer's practices.It was also observed from the data of front line demonstration recorded higher gross return and net return as compared to local check. The gross and net returns were found Rs. 38800 and Rs. 23200 in CFLD while in farmer's practices these were found Rs. 31160 and Rs. 16160, respectively.

How to cite this article : Bhargav, K.S., Gupta, Nishith, Pandey, Ankita, Patel, Neerja and Dixit, A.K. (2017). Impact of front line demonstration on production and productivity of summer moong. Agric. Update, 12(TECHSEAR-6) : 1656-1659; DOI: 10.15740/HAS/AU/12. TECHSEAR(6)2017/1656-1659. 